\title{
Comparing Method Analysis for Lower Steam Temperature of 660MW Supercritical Lignitic Boiler
}

\author{
Zhenning Zhao ${ }^{1 *}$,Yuanyuan $\mathrm{Li}^{2}$,QingfengZhang ${ }^{3}$,Jinjing $\mathrm{Li}^{4}$ \\ ${ }^{1,2,3,4}$ North China Electric Power Science Research Institute Co. Ltd., Beijing, China \\ ${ }^{*}$ Corresponding author
}

\begin{abstract}
The problem of lower main steam temperature(MST) of a supercritical boiler designed for burning high moisture lignite is analyzed. By comparing to another structure-similar subcritical boiler, the effects of coal, furnace size, combustion mode and heating surface distribution are studied. The results show that the major cause of this lower MST problem is unduly decline of high temperature heating area due to over-estimating the heat transfer capability of the upper furnace water wall of the supercritical boiler. At last, this document suggests to the increase the size of rear part of partition platen superheater(SH) to solve the problem and has a certain actual guiding reference.
\end{abstract}

Keywords-component; supercritical unit; boiler; low main steam temperature; super heater

\section{INTRODUCTION}

The consumption of lignite rises up due to its large storage in China[1]. Lignite coal is a kind of low-grade coal with high moisture and low heat value, but it has a lower price and less pollution because of its massive opencast mining mode [2]. Many researchers focused on lignite drying principle, drying technology [3-6] and characteristics of dried lignite[7,8]. Yan et al. [9] studied the impacts of dried lignite on economy of power plant. Hua[10] researched the character of lignite and the effect on boiler design. Wang et al. [11] summarized the running conditions of many domestic lignite units and proposed the power-generation technical route of the Guohua Indonesia Plant. Li [12] and Zhang et al. [13] have done lots of studies about the peculiarity of lignitic coal power plants and units on the basis of the characteristic research of high moisture lignite. Wu et al. [14] proposed the transformation plan to solve security issues of blended lignitic coal in 200MW boiler of Qinghe Plant. Although there are many researches about lignite, many problems exist in the process, one is the lower MST problem in some high moisture lignite power plants.

The MST is an important indicator of the safety and economy in power plants. Normally the rated MST is controlled at a $\pm 5{ }^{\circ} \mathrm{C}$ deviation. It has been estimated that a $10{ }^{\circ} \mathrm{C}$ of MST reduction would increase standard coal consumption by 0.2 percent. Commonly the superheaters are a little affluently designed and the MST can be controled by contempeter adjustment at the design level. Most of MST problems can be sovlved by combustion adjust, For example, a good result was achieved by taking measures of lowering the heat absorption of the furnace water wall using fuel gas impulse surge soot blower[17]. Liu et al. [18]conducted that the higher volatility and moisture were the major factors causing lower main steam temperature by analysis of the running condition of a SG42/13.7-W756 boiler and adjusting burner angle lay heat insulate layer were effective methods to raise the MST. Liu[19] believed that a sensible design of the controlling tactics are important and worth mentioning, means to regulate MST by increasing or decreasing the spray water flux. Duan et al. [20]proposed that the most important method was adjusted coordinated control strategy, feed-water control strategy and temperature control strategy synthetically.

But during the operating of the supercritical boiler No.5 of a power plant in Inner Mongolia, the MST keeps lower although almost all of these related adjustment measure a applie and the spray water flux is 0 . At rated output conditions, the design value of the MST is $571^{\circ} \mathrm{C}$, but the actual value never reach $560^{\circ} \mathrm{C}$ and the lowest is $534^{\circ} \mathrm{C}$. In this paper, all factors related to MST are studied in order to find the root causes by comparing with a structure-similar subcritical boiler, boiler No.1 of the same power plant and made by the same works. According to the root causes, analysis and puts forward the corresponding solutions.

\section{EQUIPMENT AND EXISTING PROBLEMS}

Boiler No.5 is a HG-2141/25.4-HM15 type sliding pressure once-through boiler produced by Haerbin Boiler Works and equipped with a 600MW steam turbine. This boiler is the first supercritical boiler designed specially for the high moisture Shengli Lignite of Xilinhaote in China. Its precursors, boiler from No. 1 to No. 4, with type of HG-2070 / 17.5-HM8, made by the same Works, are the first special designed Shengli Liginite subcritical type in China, adopt optimized technics basically developed from ABB-CE to adapt the high moisture and high volatile lignite, have almost the same structure except the Low NOx combustion technologies of the separated over fire air (SOFA) adopted by boiler No.5. Many problems of subcritical boilers such as under capacity, severe slagging in furnace, higher exhausting temperature and so on, are solved one by one after long-time equipment improvement and combustion adjustment and these boilers had run safely and steadily with the normal parameters for above $2 \sim 3$ years before the birth of boiler No.5. Although the supercritical boiler is designed upon the operation experiences of those subcritical boilers indeed, but the new MST problem appears, always low at the output scope of $500 \sim 600 \mathrm{MW}$. It's an efficient way to analyze by comparing the steam temperaturerelated factors such as design coal, combustion system, heating surface distribution and other characteristics.The compared results of actual values and the design values is 
shown in Table 1. In the event of heavy output, the main steam temperature never reach $560^{\circ} \mathrm{C}$. The max difference between actual value and the design value is $37^{\circ} \mathrm{C}$ in $590 \mathrm{MW}$ output.

TABLE I. THE COMPARISON OF ACTUAL MST AND THE DESIGN MST

\begin{tabular}{|c|c|c|c|c|}
\hline conditions & $\begin{array}{c}\text { unit } \\
\text { output(MW) }\end{array}$ & $\begin{array}{c}\text { design } \\
\text { values }\left({ }^{\circ} \mathrm{C}\right)\end{array}$ & $\begin{array}{c}\text { actual } \\
\text { value }\left({ }^{\circ} \mathrm{C}\right)\end{array}$ & $\begin{array}{c}\text { difference } \\
\left({ }^{\circ} \mathrm{C}\right)\end{array}$ \\
\hline 1 & 500 & 571 & 555 & 16 \\
\hline 2 & 520 & 571 & 556 & 15 \\
\hline 3 & 535 & 571 & 558 & 13 \\
\hline 4 & 580 & 571 & 562 & 19 \\
\hline 5 & 590 & 571 & 534 & 37 \\
\hline 6 & 600 & 571 & 547 & 24 \\
\hline 7 & 625 & 571 & 556 & 15 \\
\hline 8 & 630 & 571 & 557 & 14 \\
\hline
\end{tabular}

\section{CAUSE ANAlysis By COMPARING MEthoD}

\section{A. Coal}

The design coal parameters of the two boilers are listed in Table.2. Relative to those kernel components such as carbon and volatile, most of external moisture content and ash content are sneaking in outer composition, play an important role in calorific value and proportion of each component, but have relatively little effect to the combustion and slagging properties when these two content biases are not too large. In order to comparing the difference of these two design coal, the moisture content and ash content are corrected to the same level of subcritical boiler design coal based on conservation of mass law, then estimate the net calorific value with Mendeleev formula

$Q_{\mathrm{ar}, \mathrm{net}}=4.1868\left[81 C_{\mathrm{ar}}+246 H_{\mathrm{ar}}-26\left(O_{\mathrm{ar}}-S_{\mathrm{ar}}\right)-6 M_{\mathrm{ar}}\right]$

where: $Q_{\text {ar.net }}$ denotes net calorific value, $\mathrm{kJ} / \mathrm{kg} ; C_{\mathrm{ar}}$ denotes mass carbon content, \%; $H_{\mathrm{ar}}$ denotes mass hydrogen content, \%; $O_{\mathrm{ar}}$ denotes mass oxygen content, \%; $S_{\mathrm{ar}}$ denotes mass sulfur content, \%; $M_{\mathrm{ar}}$ denotes mass moisture content, \%;

TABLE II. THE COMPARE OF COAL OF THESE TWO BOILER

\begin{tabular}{|c|c|c|c|c|}
\hline \multirow[b]{2}{*}{ Items } & \multirow{2}{*}{$\begin{array}{l}\text { Subcritic } \\
\text { al boiler }\end{array}$} & \multicolumn{2}{|c|}{ Supercritical boiler } & \multirow{2}{*}{$\begin{array}{c}\text { The } \\
\text { differen } \\
\text { ces }\end{array}$} \\
\hline & & design & corrected & \\
\hline carbon $\left(\mathrm{C}_{\mathrm{ar}}\right) / \%$ & 40.96 & 38 & 40.45 & 0.51 \\
\hline hydrogen $\left(\mathrm{H}_{\mathrm{ar}}\right) / \%$ & 2.78 & 2.59 & 2.76 & 0.02 \\
\hline oxygen $\left(\mathrm{O}_{\mathrm{ar}}\right) / \%$ & 12.27 & 11.62 & 12.37 & -0.10 \\
\hline nitrogen $\left(\mathrm{N}_{\mathrm{ar}}\right) / \%$ & 0.61 & 0.59 & 0.63 & -0.02 \\
\hline sulfur $\left(\mathrm{S}_{\mathrm{ar}}\right) / \%$ & 0.45 & 0.8 & 0.85 & -0.40 \\
\hline total moisture $\left(\mathrm{M}_{\mathrm{ar}}\right) / \%$ & 29.5 & 33 & 29.51 & -0.01 \\
\hline $\begin{array}{c}\text { air dried basis } \\
\text { moisture }\left(\mathrm{M}_{\mathrm{ad}}\right) / \%\end{array}$ & 14.71 & 14.71 & 14.71 & 0 \\
\hline volatile $\left(\mathrm{V}_{\mathrm{daf}}\right) / \%$ & 46.8 & 46.91 & 49.93 & -3.13 \\
\hline $\begin{array}{l}\text { received basis } \\
\text { ash }\left(\mathrm{A}_{\mathrm{ar}}\right) / \%\end{array}$ & 13.43 & 13.4 & 13.44 & -0.01 \\
\hline $\begin{array}{c}\text { net calorific } \\
\text { value }\left(Q_{\text {ar,net }}\right) / \mathrm{kJ} \cdot \mathrm{kg}^{-1}\end{array}$ & 14720 & 13400 & 14470 & 250 \\
\hline $\begin{array}{l}\text { Distortion temperature } \\
(\mathrm{DT}) /{ }^{\circ} \mathrm{C}\end{array}$ & 1100 & 1100 & & \\
\hline $\begin{array}{l}\text { Softening temperature } \\
(\mathrm{ST}) /{ }^{\circ} \mathrm{C}\end{array}$ & 1140 & 1140 & & \\
\hline $\begin{array}{l}\text { Fluiding temperature } \\
(\mathrm{FT}) /{ }^{\circ} \mathrm{C}\end{array}$ & 1220 & 1200 & & \\
\hline
\end{tabular}

As shown in Table.2, it can be concluded that the element content differences between the design coal of subcritical boiler and the corrected value of supercritical boiler design coal are very tiny. The Mendeleev formula calculated net calorific value of supercritical boiler is $16680 \mathrm{~kJ} / \mathrm{kg}$, only $209 \mathrm{~kJ} / \mathrm{kg}$ different from the net calorific value of subcritical boiler design coal. Otherwise, the 3 ash fusion temperatures are also identical. So these two kinds of coals can be considered as same, could not lead to evident boiler design difference. The actual two boiler structures are very similar and the actual burning coal are fully same, so the fuel is not the cause of performance difference the boiler.

\section{B. The Furnace Structure and Combustion System}

Both boilers use the welded memberane water wall structure to build furnace. For the furnace of supercritical boiler, the cross-section dimension is $20.4023 \mathrm{~m} \times 20.0723 \mathrm{~m}$, the longitudinal section area is $409.5 \mathrm{~m}^{2}$, the volume is 27339 $\mathrm{m}^{3}$ and the furnace height is $62.734 \mathrm{~m}$. For the subcritical boiler, the cross-section dimension is $20.193 \mathrm{~m} \times 20.052 \mathrm{~m}$, the longitudinal section area is $404.9 \mathrm{~m}^{2}$, the volume is $26278 \mathrm{~m}^{3}$ and the furnace height is $65.251 \mathrm{~m}$. Obviously the supercritical boiler has a very similar but a little larger furnace than the subcritical boiler, and this largerment is good for raising the steam temperature. So the difference of furnace dimension is not the main causes of lower steam temperature.

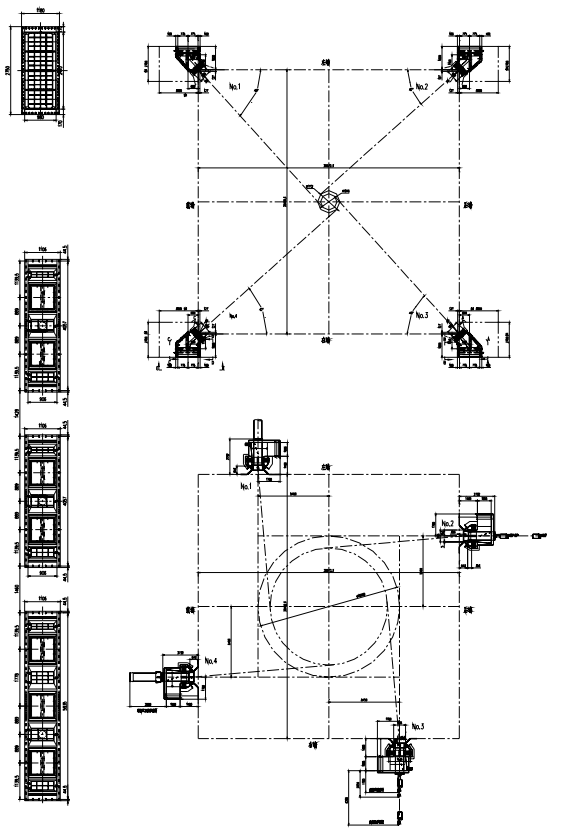

FIGURE I. BURNER ARRANGEMENT OF BOILER NO.5

Both boilers adopt tangential combustion technology. The subcritical boiler adopts the common four corner tangential firing mode, the supercritical boiler applies newly developed four wall tangential firing mode with same size imaginary tangential circle. To reduce flue gas $\mathrm{NO}_{\mathrm{x}}$ emission concentration, two set of separated corner tangential burners are used in SOFA burnout zone are applied on the supercritical boiler, which is about 3 meters above the highest burner of subcritical boiler, as shown in Figure.1. The distance of 
burnout flame is $24.066 \mathrm{~m}$ of the subcritical boiler is a littler shorter than that of $24.245 \mathrm{~m}$ of the supercritical boiler. So The flue gas temperature in the upper furnace is higher because of the combustion delay of SOFA technology, also good for raising the steam temperature. So the difference of combustion mode is not the reason of the lower MST for boiler No.5.

\section{Heat Absorption Capacity of the Superheaters}

The main design data and calculated values of valid heat absorption by unit water-steam of the two boilers are shown in Table 3. Under the design condition, the total valid heat consumption bias per unit water-steam between the two boilers is less than $3 \mathrm{~kJ} / \mathrm{kg}$. Meanwhile, the supercritical boiler furnace exit design flue gas temperature is only $6^{\circ} \mathrm{C}$ higher than that of subcritical boiler, shows that the total furnace radiation heat releases, the convection heat exchange of the two boilers are also almost equal accordingly. For superheaters, heat transfer temperature differences between flue gas and steam are also similar if they are placed at the same flue gas position, such as final superheater, their temperature rises can be compared by size of their heating surface area.

Commonly, superheaters consist of the front division platen superheater (FPSH), the rear platen superheater (RPSH), the final superheater (FSH), the vertical low-temperature superheater (VLTSH) and the level low-temperature superheater (LTSH). The FPSH, the RPSH and the FSH have a much bigger temperature difference than the VLTSH and LTSH. So we can consider the first three as high temperature difference superheater (HTD SHs) and the last two as low temperature difference superheaters (LTD SHs) for convenience. The HTD SH has more powerful heat exchange capacity the LTD SHs if their exchange areas are same. For these two boilers, conditions of each superheaters are shown in Table.4.

By comparing the heating surface distribution of the two boilers, it can be concluded that: 1) The platen superheater area including FPSH and RPSH of subcritical boiler No.1 is 2.3 times of that of supercritical boiler No.5. The FSH area of boiler No.1 is also about 2 times about that of boiler No.5, means that the absorption of HTD SHs of boiler No.1 is much higher than boiler No.5. 2) Although the LTD SHs heating surfaces Area of boiler No. 1 is $3239 \mathrm{~m}^{2}$ less than that of boiler No.5. But the total heating surface area of boiler No.1 is 2071 $\mathrm{m}^{2}$ more than that of boiler No.5. Obviously, the superheaters' heat absorption capacity of boiler No.5 is much lower than that of No.1 boiler.

TABLE III. THE MAIN DESIGN OF THE TWO BOILERS

\begin{tabular}{|c|c|c|c|c|c|c|}
\hline \multirow{2}{*}{ Items } & \multicolumn{3}{|c|}{ supercritical boiler No.5 } & \multicolumn{3}{|c|}{ subcritical boiler No.1 } \\
\hline & BMCR & TRL & 75\% ТНА & BMCR & TRL & 75\%ТНА \\
\hline Main steam flow / $t \cdot h^{-1}$ & 2141 & 2078.65 & 1391.1 & 2070 & 1895 & 1149 \\
\hline Main steam outlet pressure / MPa & 25.4 & 25.33 & 20.65 & 17.5 & 17.31 & 17.02 \\
\hline Main steam outlet temperature $/{ }^{\circ} \mathrm{C}$ & 571 & 571 & 571 & $541 \pm 5$ & $541 \pm 5$ & $541 \pm 5$ \\
\hline Drum separator pressure / MPa & 26.81 & 26.66 & 21.38 & 18.5 & 18.5 & 18.5 \\
\hline Drum separator temperature $/{ }^{\circ} \mathrm{C}$ & 425 & 424 & 389 & 360 & 360 & 360 \\
\hline SH inlet enthalpy ${ }^{(1)} / \mathrm{kJ} \cdot \mathrm{kg}^{-1}$ & 2741 & 2741 & 2668 & 2509 & 2509 & 2509 \\
\hline SH outlet enthalpy ${ }^{(1)} / \mathrm{kJ} \cdot \mathrm{kg}^{-1}$ & 3401 & 3401 & 3450 & 3395 & 3395 & 3395 \\
\hline Total SH enthalpy rise ${ }^{(1)} / \mathrm{kJ} \cdot \mathrm{kg}^{-1}$ & 660 & 660 & 782 & 886 & 886 & 886 \\
\hline Total SH temperature rise ${ }^{(1)} /{ }^{\circ} \mathrm{C}$ & 146 & 147 & 182 & 181 & 181 & 181 \\
\hline Reheat steam flow rate / $\mathrm{t} \cdot \mathrm{h}^{-1}$ & 1742 & 1684.3 & 1166.1 & 1654 & 1495 & 1149 \\
\hline Reheat steam outlet temperature $/{ }^{\circ} \mathrm{C}$ & 569 & 569 & 569 & $541 \pm 5$ & $541 \pm 5$ & $541 \pm 5$ \\
\hline Reheat steam inlet temperature $/{ }^{\circ} \mathrm{C}$ & 328.3 & 324.4 & 310.6 & 330 & 321 & 300 \\
\hline Furnace outlet temperature $/{ }^{\circ} \mathrm{C}$ & 964 & 957 & 878 & 958 & 943 & 900 \\
\hline Exhausting flue gas temperature $/{ }^{\circ} \mathrm{C}$ & 146.5 & 145.4 & 131.7 & 145 & 143 & 126 \\
\hline Design low calorific value $/ \mathrm{kJ}^{\mathrm{k}} \mathrm{kg}^{-1}$ & 13400 & 13400 & 13400 & 14720 & 14720 & 14720 \\
\hline Total coal flow rate $/ \mathrm{t}^{-1}$ & 445.64 & 434.99 & 312.78 & 388.8 & 357 & 275.6 \\
\hline Boiler efficiency/\% & 92.04 & 92.13 & 92.23 & 93.02 & 93.17 & 93.16 \\
\hline Total valid heat input ${ }^{(2)} / \mathrm{MJ}$ & 5496 & 5370 & 3866 & 5324 & 4896 & 3779 \\
\hline Furnace section heat output $/ \mathrm{MW} \cdot \mathrm{m}^{-2}$ & 4.030 & 3.934 & 2.817 & 3.93 & 3.74 & 2.69 \\
\hline Furnace volume heat output $/ \mathrm{kW} \cdot \mathrm{m}^{-3}$ & 60.37 & 58.93 & 42.20 & 60.5 & 57.6 & 41.5 \\
\hline Unit heat absorption $/ \mathrm{kJ} \cdot \mathrm{kg}^{-1}$ & 2567 & 2582 & 2779 & 2571 & 2583 & 3289 \\
\hline
\end{tabular}

Note:(1)calculate according to temperature and pressure of steam and water.

(2)It is the product of coal flow rate, net low calorific value and boiler efficiency. 
TABLE IV. CONDITIONS OF HEATING SURFACE OF THE TWO BOILERS

\begin{tabular}{|c|c|c|c|c|c|c|}
\hline \multirow{2}{*}{\multicolumn{2}{|c|}{ Items }} & \multicolumn{3}{|c|}{ HTD SHs area } & \multicolumn{2}{|c|}{$\begin{array}{c}\text { LTD SHs } \\
\text { area }\end{array}$} \\
\hline & & \multirow{2}{*}{$\begin{array}{c}\text { FPSH } \\
51\end{array}$} & \multirow{2}{*}{$\begin{array}{r}\text { RPSH } \\
60 / 57\end{array}$} & \multirow{2}{*}{$\begin{array}{c}\text { FSH } \\
60\end{array}$} & VLT & LT \\
\hline \multirow{4}{*}{$\begin{array}{c}\text { boiler } \\
\text { No.1 } \\
\text { (600MW) }\end{array}$} & $\begin{array}{l}\text { External tube } \\
\text { diameter/mm }\end{array}$ & & & & 57 & 57 \\
\hline & \multirow{3}{*}{$\begin{array}{c}\text { Exchange } \\
\text { Area } \\
/ \mathrm{m}^{2}\end{array}$} & 2530 & 2589 & 4592 & 1717 & 11268 \\
\hline & & \multicolumn{3}{|c|}{ Sum: 9711} & \multicolumn{2}{|c|}{ Sum: 12985} \\
\hline & & \multicolumn{5}{|c|}{ Sum: 22696} \\
\hline \multirow{4}{*}{$\begin{array}{c}\text { boiler } \\
\text { No.5 } \\
\text { (660MW) }\end{array}$} & $\begin{array}{l}\text { External tube } \\
\text { diameter/mm }\end{array}$ & $57 / 51$ & no & $63 / 51$ & 51 & 51 \\
\hline & \multirow{3}{*}{ Area $/ \mathrm{m}^{2}$} & 2203 & no & 2199 & 1166 & 15057 \\
\hline & & & um: 440 & & Sum & 6223 \\
\hline & & \multicolumn{5}{|c|}{ Sum: 20625} \\
\hline
\end{tabular}

D. The Reason of Smaller Convection Heating Surface of Supercritical Boiler

The higher the steam pressure is, the lesser the evaporation heat(latent heat) of steam is, means lesser furnace radiation surface are needed more heat to high up the steam temperature. To utilize these superfluous evaporating surface, modern supercritical boiler design upper water wall as labile superheater. Firstly under very low output, the boiler works under wet cycling condition, the steam separator works as a drum, the working material in the wall tubes is mixed water and steam, just as the subcritical boiler; Then the boiler output goes into subcritical once-through dry state, the steam separator works as a pass through component, but all of the wall still works as an evaporator, all of the water material changes into steam just at the end of wall tubes; At last, with the boiler output rises up continuously, only the lower furnace works as evaporator, the upper furnace water wall begins to act as superheater. For the boiler No.5, the once-through state output is 35\% output. Although the part of the water wall area is small, but have strong temperature rise capability due to the powerful radiation characteristic.

Mainly due to this upper furnace "superheater", those true superheater is designed lesser in boiler No.5. Figure.II is the control graph of water-steam system hard copied from DCS system under rated output after many optimizing works were conducted. The design temperature in the outlet of starting vessels is $424^{\circ} \mathrm{C}$, much higher than the critical temperature of $374^{\circ} \mathrm{C}$, but the actual temperature is only $410^{\circ} \mathrm{C}$, about $14^{\circ} \mathrm{C}$ lower than the design value. This lower input temperature makes every other heating surfaces afterwards are also lower. Otherwise, to ensure strict limited low NOx emission concentrations, much measurements must be done to lower the flame centre, make all other radiation and convective heaters in bank-end absorbed lower heat, greatly limits the compensation function the combustion adjustment to the main steam temperature. The main steam temperature rise up to design value but no or very little spray water needs be used under mid or lower output because the fraction convective heat of fuel highs up. From this, the direct reason for lower main steam temperature of boiler No.5 is lesser heating surface set due to over estimating the heat transfer capacity of the upper furnace water wall.

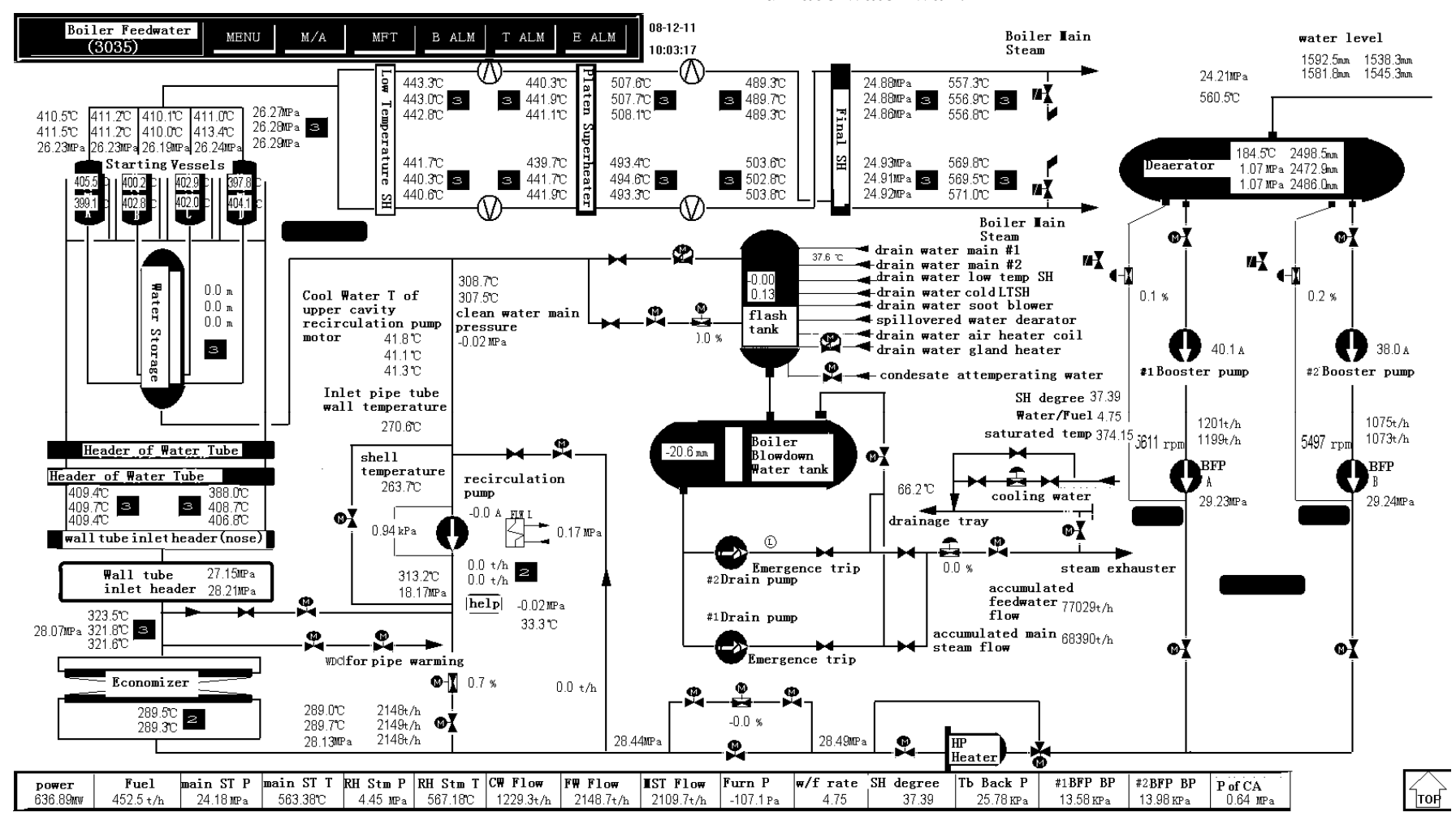

FIGURE II. WATER-STEAM SYSTEM OF BOILER NO.5 UNDER FULL OUTPUT 


\section{Method And Position of Adding Convective HEATING SURFACES}

Because the lack of rear platen superheater, As shown in Figure.III, it is the best to double platens of the right half of the division platen superheaters, let it works as the rear platen superheater just like boiler No.1.

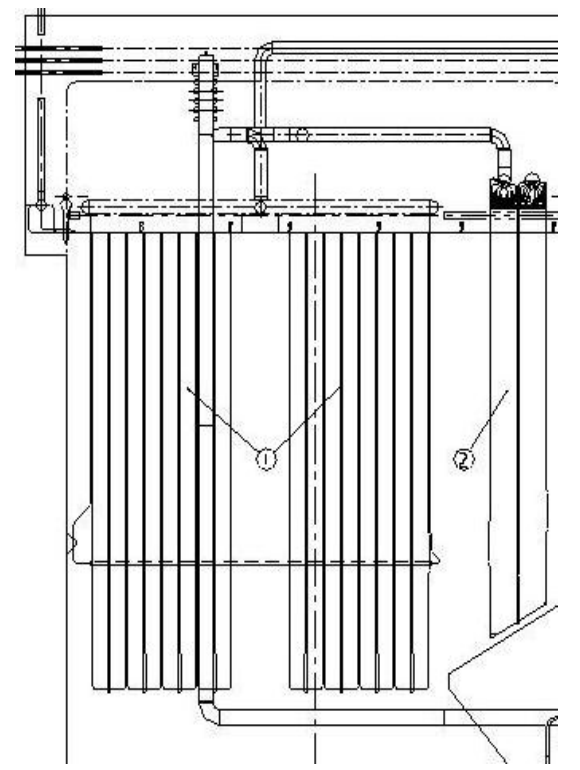

(1)division platen superheater (2)final superheater.

FIGURE III. PLATEN SUPERHEATERS OF BOILER NO.5

\section{CONCLUSIONS}

The supercritical boiler design is based on the subcritical boiler, so the size and structure of the two boilers are similar. By comparing the two consanguineous boiler's design, the cause of lower main steam temperature is found. Mainly due to over estimating the capacity of the upper furnace water superheater, rear platen superheaters are set as division platen superheater in the design of supercritical boiler. The best way to solve this problem is to double the rear part of the division platen superheater.

\section{REFERENCES}

[1] Song B.J, Hao L.L. Brief Analysis of Current Status and Developing Trend of Large Capacity and High Efficiency Lignite-fired Boiler [J]. Boiler Manufacturing, 2007, (02)

[2] Guo X.K, Xiao F,YanJ.J, et al. Study on Efficient Lignite-fired Power System. Proceedings of the CSEE.2011, 9, 31(26):23-31

[3] Calban T, ErsahanH. Drying of a Turkish lignite in a batch fluidized bed[J]. Energy Sources, 2003,25(12):1129-1135

[4] Wan Y.Z, Xiao L, Tao X.X, et al. Lignite predrying dehydration technology progress[J].Coal Engineer, 2008(8): 91-93

[5] Meng S, Sun S.Z, Zhao G.B. Lignite predrying dehydration technology[J]. Thermal Energy and Power Engineering, 2013(2):35-37

[6] Agraniotis M, Grammelis P, Papapavlou C, et al. Experimental investigation on the combustion behavior of pre-dried Greek lignite[J]. Fuel Processing Technology, 2009, 90(9):1071-1079

[7] Hoehne O, Lechner S, Schreiber M, et al. Drying of lignite in a pressurized steam fluidized bed-theory and experiments[J]. Drying
Technology, 2010, 28(1):5-19

[8] Tian Z.K, Zhu S.Q.The Applied Research ofIntegration Accelerating Cyclone Drying Equipment in Lignite-fired Power Plant[J].Clean Coal Technology,2007,13(5): 75-79

[9] Yan W.P, Ma K, Li C.Q, et al. Economical Effect of Lignite coal drying on Lignite-fired Electric Power Plant[J]. Electric Power,2010,43(3): 35-37

[10] Hua S.Q.The Characteristics of Lignite and Influence on Boiler Design[J]. Power System Engineering,1991(4)

[11] Wang J, Yu X.H, Zhou H.B, et al. Discussion on the Roadmap of Generation Technologies using High Moisture Indonesian Lignite[J]. Electric Power, 2014, 12,47(12):1-7

[12] Li W.D, Zhang Y, Xu C.K, Zhang J.W. Selection of Combustion Equipments for Lignite Fired Boiler[J]. Electric Power, 2011, 44(2):4953

[13] Zhang D.J, Yin X.M. Study and Basic Design of a 1000MW Ultrasupercritical Lignite-fired Boiler[J]. Journal of Chinese Society of Power Engineering, 2010, 30(8):559-566

[14] Wu J.X, Chen Q.G, Ma J.F, Wang L, Leng J. Feasibility Study on the Hot Flue Gas Mixture in Coal Pulverizing System of Boiler of 200 MW[J]. Electric Power, 2006, 39(3):22-25

[15] Liu G.H. The Cause and Solution Method on Main Stream Temperature Low of WenDeng Power Plant Boiler[J]. Science Technology Information, 2013, 23:111

[16] Lin J.Z. The Cause and Preventive Measure Main Stream Temperature Low[J].Electric Safety Technology, 2005,7(2): 12-13

[17] Liu H.Y, He T. Solution Method on Main Stream Temperature[J]. Science and Technology Innovation Herald, 2008, 8:93

[18] Liu M.S, Zhang Q, Yang X.F, Xie B.F, Sun Z.L, Zhao C.J, Fei Q. Cause Analysis and Solution Method Discussion on the Main Stream Temperature Low of a 420t/h Boiler[J]. Energy Engineering,2011(4): 57-62

[19] Liu B.600 MW Supercritical W Flame Boiler Coordination and Main Steam Temperature Control Optimization[J]. Hunan Electric Power,2014,34(1): 23-26

[20] Duan S.T, Li S.S. Cause Analysis on Main Steam Temperature Fluctuations of $660 \mathrm{MW}$ Ultra Supercritical Unit[J]. Electric Power.2010, 10, 43(10):39-43 